\title{
The validity of footprint-based measures of arch structure: revisiting the debate of fat versus flat feet in adults
}

\author{
Hin-Chung Lau ${ }^{1,2^{*}}$, Scott C Wearing ${ }^{1,2}$, Nicole L Grigg ${ }^{3}$, James E Smeathers ${ }^{3}$ \\ From 3rd Congress of the International Foot and Ankle Biomechanics Community \\ Sydney, Australia. 11-13 April 2012
}

\section{Background}

Previous research employing footprint-based measures of arch structure, such as the arch index (AI), have indicated that obesity results in a 'flatter' foot type [1]. In the absence of radiographic measures, however, definitive conclusions regarding the osseous alignment of the foot cannot be made. This study evaluated the effect of Body Mass Index (BMI) on radiographic and footprintbased measures of adult arch structure.

\section{Materials and Methods}

A convenience sample of 30 healthy adults (10 male and 20 female, mean $( \pm$ SD) age $47.9 \pm 11.6$ years, height $1.68 \pm 0.1 \mathrm{~m}$, body weight $80.8 \pm 10.2 \mathrm{~kg}$, BMI $28.8 \pm$ $2.9 \mathrm{~kg} \cdot \mathrm{m}^{-2}$ ) were recruited. The calcaneal-first metatarsal angle (CMT1) (Figure 1a) was derived from weightbearing lateral radiographs [2], while the AI was calculated from electronic footprints (EMED-SF, Novel $\mathrm{GmbH}$, Germany) as the ratio of the area of the midfoot relative to the total foot contact area ignoring the digits
(Figure 1b). Multiple regression models were used to evaluate the independent influence of BMI, age, and arch structure (as defined by CMT1 angle) on the footprint-based AI, and investigate whether BMI, age, and AI were significant predictors of CMT1 angle.

\section{Results}

Both BMI $(\beta=0.39, P=0.04)$ and CMT1 angle $(\beta=0.51$, $\mathrm{P}<0.01)$ were significant predictors of footprint-based measures of arch structure (AI). The CMT1 angle accounted for $30 \%$ of the variability in AI, while BMI accounted for $15 \%$ of the variation in AI. In contrast, CMT1 angle was not significantly associated with BMI $(\beta=-0.03, \mathrm{P}=0.89)$ when $\mathrm{AI}$ and age were held constant. Age was not a significant predictor of either index.

\section{Conclusions}

Adult obesity does not influence the osseous alignment of the medial longitudinal arch, but selectively distorts footprint-based measures of arch structure. Conse-
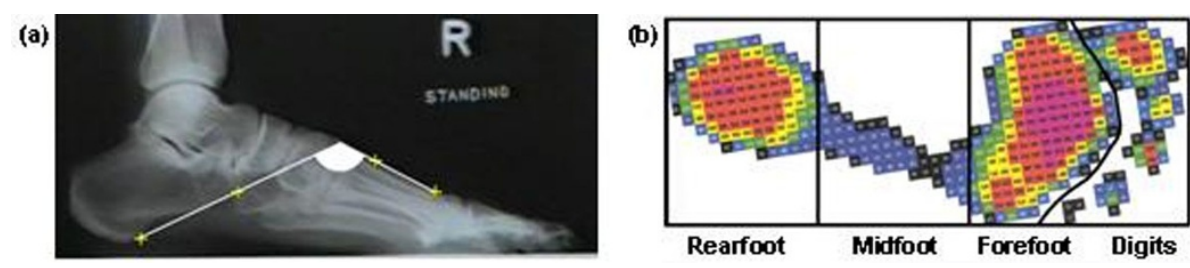

Figure 1 Illustration of radiographic (a), and footprint-based measures of arch structure (b).

\footnotetext{
* Correspondence: lauhinchung@gmail.com

${ }^{1}$ Faculty of Health Sciences and Medicine, Bond University, Queensland,

4229, Australia

Full list of author information is available at the end of the article
}

(c) 2012 Lau et al; licensee BioMed Central Ltd. This is an Open Access article distributed under the terms of the Creative Commons 
quently, footprint-based measures should be interpreted with caution when comparing groups of adults with varying body composition.

\section{Acknowledgements}

Mr Lau is funded through an Australian Research Council Linkage Grant and a Queensland Academy of Sport Fellowship. Dr Wearing is funded through a Smart Futures Fellowship, Department of Employment, Economic

Development and Innovation, Queensland Government.

\section{Author details}

${ }^{1}$ Faculty of Health Sciences and Medicine, Bond University, Queensland, 4229, Australia. ${ }^{2}$ Centre of Excellence for Applied Sport Science Research, Queensland Academy of Sport, Queensland, 4111, Australia. Institute of Health and Biomedical Innovation, Queensland University of Technology, Queensland, 4059, Australia.

Published: 10 April 2012

\section{References}

1. Gravante G, Russo G, Pomara F, et al: Comparison of ground reaction forces between obese and control young adults during quiet standing on a baropodometric platform. Clin Biomech 2003, 18:780-782.

2. Wearing S, Smeathers J, Yates B, et al: Sagittal movement of the medial longitudinal arch is unchanged in plantar fasciitis. Med Sci Sports Exerc 2004, 36:1761-174.

doi:10.1186/1757-1146-5-S1-054

Cite this article as: Lau et al:: The validity of footprint-based measures of arch structure: revisiting the debate of fat versus flat feet in adults. Journal of Foot and Ankle Research 2012 5(Suppl 1):054.

\section{Submit your next manuscript to BioMed Central} and take full advantage of:

- Convenient online submission

- Thorough peer review

- No space constraints or color figure charges

- Immediate publication on acceptance

- Inclusion in PubMed, CAS, Scopus and Google Scholar

- Research which is freely available for redistribution

Submit your manuscript at www.biomedcentral.com/submit 